Publisher: GSA

Journal: GEOL: Geology

DOI: $10.1130 / \mathrm{G} 39892.1$

\title{
1 Diatom ooze: Crucial for the generation of submarine
}

2 mega-slides?

3 Morelia Urlaub ${ }^{1}$, Jacob Geersen ${ }^{1}$, Sebastian Krastel ${ }^{2}$, and Tilmann Schwenk ${ }^{3}$

$4 \quad{ }^{1}$ Geomar Helmholtz Centre for Ocean Research Kiel, 24148 Kiel, Germany

$5 \quad{ }^{2}$ Institute of Geosciences, Kiel University, 24118 Kiel, Germany

$6{ }^{3}$ MARUM-Center for Marine Environmental Sciences and Faculty of Geosciences,

7 University of Bremen, 28359 Bremen, Germany

8 ABSTRACT

9 Numerous studies invoke weak layers to explain the occurrence of submarine

10 mega-slides $\left(>100 \mathrm{~km}^{3}\right)$, in particular those on very gentle slopes $\left(<3^{\circ}\right)$. Failure

11 conditions are thought to be met only within this layer, which is embedded between

12 stable sediments. Although key to understanding failure mechanisms, little is known

13 about the nature and composition of such weak layers, mainly because they are destroyed

14 with the landslides. This study is the first to place detailed constraints on the weak layer

15 for one of the submarine mega-slides that occurred on the nearly flat subtropical

16 Northwest African continental slopes. Integrating results from the Ocean Drilling

17 Program with high resolution seismic reflection data we show that the failure surfaces

18 traced into the undisturbed sedimentary sequence coincide with thin $(<10 \mathrm{~m})$ diatom ooze

19 layers capped by clay. As diatom oozes are common on many continental margins, we

20 suggest a new margin-independent failure mechanism to explain submarine mega-slides

21 at low gradient continental slopes globally. Diatom oozes are susceptible to building up

22 excess pore fluid during burial due to their high compressibility and water content. If a 
Publisher: GSA

Journal: GEOL: Geology

DOI:10.1130/G39892.1

23 low permeable clay cap prevents upward drainage, excess pore pressures accumulate in

24 the ooze-clay interface causing the shearing resistance to increase at a lower rate than the

25 shear stress until failure can occur. Changes in global climate affect the abundance of

26 diatoms and thus formation of diatom oozes, thereby preconditioning the sediments for

27 failure. However, the actual timing of failure is independent of environmental changes.

\section{INTRODUCTION}

29 Submarine landslides are the largest mass movements on Earth, and they can be

30 far larger than any terrestrial slope failure (Masson et al., 2006). For example, the giant

31 Storegga Slide offshore Norway that occurred $\sim 8,150$ years ago moved $>3000 \mathrm{~km}^{3}$ of

32 slope sediments. It triggered a North Atlantic wide tsunami that inundated surrounding

33 coasts to heights of up to $20 \mathrm{~m}$ (Bondevik et al., 2005). For comparison, collapse of Mt St

34 Helens volcano in 1980 involved $\sim 3 \mathrm{~km}^{3}$ of rock material (Voight et al., 1983), while the

35 annual global flux of sediment from rivers into the ocean is $\sim 11 \mathrm{~km}^{3}$ (Milliman and

36 Syvitski, 1992).

37 Submarine landslides occur globally, but the largest $\left(>100 \mathrm{~km}^{3}\right)$ events have

38 occurred along gently inclined $\left(<3^{\circ}\right)$ slopes on passive continental margins in areas with

39 thick fine-grained sedimentary deposits (Masson et al., 2006). The majority of these

40 mega-slides are translational, such that failure takes place along bedding-parallel surfaces

41 (called glide planes). Commonly, sliding involves several glide planes at different

42 stratigraphic depths, leaving behind staircase morphologies. It appears that the wide

43 spatial extent of these landslides is due to the absence of major morphological breaks and

44 geological discontinuities over wide areas. This suggests that distinct 'weak layers' 
Publisher: GSA

Journal: GEOL: Geology

DOI:10.1130/G39892.1

45 capable of accommodating slope failure may form over thousands of square kilometers

46 (Masson et al., 2010).

The most compelling constraints on weak layers come from Finneidfjord in

48 Norway (a thin turbidite of stratified sand and clay; L'Heureux et al., 2012) and the

49 catastrophic 1979 Nice airport landslide (a sensitive clay layer that was weakened by

50 pore fluid flow; Dan et al., 2007). However, these are small submarine landslides that

51 occurred on relatively steep slopes. For giant submarine landslides on very gentle slopes

52 the composition and nature of weak layers is poorly documented. This is because

53 sediment cores that penetrate the failure surface typically show landslide debris directly

54 overlying undisturbed older sediment. The weak layer has thus been destroyed by slide

55 movement, and the sediment from which the weak layer consisted has vanished with the

56 landslide. To date, the only detailed study on a weak layer of a giant submarine landslide

57 comes from the well-studied Storegga Slide, where the weak layer corresponds to glacial

58 marine clay with strain softening behavior (Kvalstad et al., 2005).

59 Here, we provide the first detailed study of a weak layer associated with a

60 submarine mega-slide at a subtropical continental margin: the Cap Blanc Slide off

61 Northwest Africa (Fig. 1). Using high resolution seismic reflection data, we trace the

62 failure surfaces of three landslides to Ocean Drilling Program (ODP) Site 658

$63\left(20^{\circ} 44^{\prime} 57^{\prime \prime} \mathrm{N}, 18^{\circ} 34^{\prime} 51^{\prime \prime} \mathrm{W}, 2263 \mathrm{~m}\right.$ water depth). The ODP core recovered $\sim 300 \mathrm{~m}$ of

64 sediment including one glide plane as well as undisturbed sedimentary sequences

65 including two failure surfaces linked to two landslides that have occurred at some

66 distance to the core. This setting thus provides the unique opportunity to identify the

67 weak layers responsible for the Cap Blanc Slide. We then develop a novel and widely 
Publisher: GSA

Journal: GEOL: Geology

DOI:10.1130/G39892.1

68 applicable model for the landslide failure mechanism, which can explain the occurrence

69 of many large submarine landslides worldwide.

\section{METHODS}

Seismic data was acquired using a GI Gun with 2x1.7 1 chamber volume and a

$72500 \mathrm{~m}$ long analogue streamer hosting 80 channels (see the GSA Data Repository ${ }^{1}$ for

73 processing details). To correlate core lithology and seismic data we visually match the

74 phases of a synthetic seismic trace calculated from core data (GRA density and initial

75 constant p-wave velocity) with recorded seismic traces (see the Data Repository). The

76 process of phase matching is iterative and includes vertical adjustment of the synthetic

77 trace ('stretching' or 'squeezing'), corresponding adaptation of the velocity profile, and

78 recalculation of the synthetic trace using the updated velocity profile, all of which is

79 integrated in the SynPAK module of The IHS Kingdom ${ }^{\circledR}$ software. Updated p-wave

80 velocities are in the range of $1.3-1.8 \mathrm{~m} / \mathrm{s}$ and thus reasonable for shallow marine

81 sediments (Press, 1966).

\section{RESULTS AND INTERPRETATION}

83 Morphology of the Cap Blanc Slide Area

84 The Cap Blanc Slide is located at the continental slope off northern Mauritania.

85 Swath bathymetric data covering parts of the slide show two main scarps with slope

86 angles between $10-20^{\circ}$ that delineate two failure surfaces (Fig. 1), which we refer to as

87 'major' slide for the larger slide and 'minor' slide to describe a smaller slide inside the

88 bigger failed area. The scarp of the major slide can be traced from the southern boundary

89 of the map toward a water depth of $1950 \mathrm{~m}$. From here it kinks to the northwest and is

90 visible for another $35 \mathrm{~km}$. Inside the area delineated by the major scarp a smaller scarp 


\section{Publisher: GSA \\ Journal: GEOL: Geology \\ DOI:10.1130/G39892.1}

91 extends to the northwest and southwest with heights of 25-50 m. The major and minor

92 landslides intersect in the headwall area. The headwall of the major slide is $100 \mathrm{~m}$ high

93 and increases to a height of almost $200 \mathrm{~m}$ where the two slides merge. The maximum

94 seabed gradient in the area is $2.8^{\circ}$. The very smooth seafloor inside both slide areas

95 indicates translational sliding along bedding parallel glide planes. The two glide planes

96 locate at different stratigraphic depths. ODP Site 658 was drilled just south of the major

97 sidewall inside the area evacuated by the major slide (Fig. 1).

\section{Seismic Data and Stratigraphic Correlation}

The slope parallel seismic line GeoB09-040 (Fig. 2) crosses the sidewalls of both

100 the major ( $\mathrm{km} \mathrm{16})$ and the minor $(\mathrm{km} \mathrm{5)}$ slide as well as ODP Site $658(\mathrm{~km} \mathrm{11).} \mathrm{In}$

101 addition, another buried slide scar is imaged $1 \mathrm{~km}$ south of Site 658, at $10 \mathrm{~km}$ inline

102 distance and $3.24 \mathrm{~s}$ TWT. None of the glide planes cut across stratigraphy, hence all

103 slides failed parallel to the bedding. We identify glide planes as the top of the uppermost

104 reflectors that are continuous across slide scars. Additional indication for glide planes are

105 local disturbances in reflector continuity (e.g., at $13.8 \mathrm{~km}$ and $3.1 \mathrm{~s} \mathrm{TWT}, 3.5 \mathrm{~km}$ and

$1063.28 \mathrm{~s}$ TWT) that represent slide debris on top of glide planes. Note that the respective

107 reflectors traced into the unfailed sections are also termed glide planes. The glide plane of

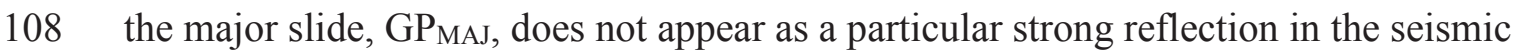

109 data. A low amplitude reflector just below a high-amplitude reflector (H05) represents

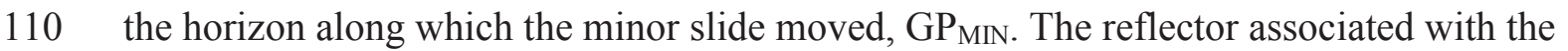

111 glide plane of the buried scar, $\mathrm{GP}_{\mathrm{BUR}}$, is marked by a reflector that is of normal polarity in

112 the failed section (south of the scarp) and of reversed polarity in the unfailed section. The

113 thickness of the failed packages are $100 \mathrm{~m}$ for the major slide, $56 \mathrm{~m}$ for the minor slide 


\section{Publisher: GSA \\ Journal: GEOL: Geology \\ DOI:10.1130/G39892.1}

114 (Fig. 2, both calculated with sound velocity of $1500 \mathrm{~m} / \mathrm{s}$ ), and $31 \mathrm{~m}$ for the buried slide

115 (estimated from the core). The horizontally layered shallow strata host nine prominent

116 high-amplitude seismic reflectors that can be traced to ODP Site 658 (H01-H09, see

117 Table DR1 in the Data Repository).

118 The core-seismic integration shows that the uppermost six seismic reflectors are

119 evenly spaced in depth and time, with $\sim 15 \mathrm{~m}$ of sediment, or $\sim 100 \mathrm{ka}$, in between

120 individual reflectors (Table DR1 in the Data Repository). The glide plane of the major

121 slide correlates with a hiatus in the drill core and is likely responsible for removing the

122 sediment deposited in the time interval between 731 and $1573 \mathrm{ka}$ (Tiedemann, 1991).

123 Ages of continuous reflectors across the scarp (i.e., the reflector directly on top of the

124 glide planes, Fig. 2) represent sediment deposited after failure and thus give a minimum

125 age of the respective slide.

\section{Sedimentology of Glide Planes and Weak Layers}

127 Figure 3 shows selected physical and sedimentological properties from ODP core 128658 in relation to seismic horizons along line GeoB09-040. The nine prominent seismic 129 reflections (H01-H09) correlate with 2-10 m thick sedimentary beds of low density, high 130 porosity, high biogenic opal content, and high element log-ratios of silica to aluminum

131 (ln(Si/Al), Fig. 3). These beds host high abundances of marine diatoms (siliceous

132 microfossils), which were deposited during the terminations of glacial periods (Meckler 133 et al., 2013; Tiedemann, 1991).

134 The weak layer of the major slide (formerly covering GPMAJ) has most likely 135 vanished with the slide material. In contrast, the weak layers for the minor and buried 136 slides are present in the ODP core because the site is located outside of their scar areas 


\section{Publisher: GSA \\ Journal: GEOL: Geology \\ DOI:10.1130/G39892.1}

137 (Figs. 1, 3). The glide plane of the minor slide, GP MIN, in $\sim 69 \mathrm{~m}$ depth lies just below

138 seismic reflector H05. H05 coincides with a $\sim 2.5 \mathrm{~m}$ thick diatom ooze layer (Tiedemann,

1391991 ) characterized by a density decrease to $1.28 \mathrm{~g} / \mathrm{cm}^{3}$ and high porosity of $72 \%$. The

140 log-ratio of $\mathrm{Si}$ and $\mathrm{Al}$ shows a prominent peak of 3.5 between 65 and $67 \mathrm{~m}$, in line with

141 an opal content maximum of $40 \%$. The sediment covering GP $\mathrm{MIN}$ yields a large clay

142 fraction of $77 \%$ extending from 60 to $66 \mathrm{~m}$, below which the clay content drastically

143 decreases to $20 \%$ at $68 \mathrm{~m}$.

144 The glide plane of the buried slide, $\mathrm{GP}_{\mathrm{BUR}}$, is located at $\sim 183 \mathrm{~m}$ in the ODP core.

145 Between $177 \mathrm{~m}$ and $181 \mathrm{~m}$ core depth a density minimum of $1.25 \mathrm{~g} / \mathrm{cm}^{3}$ and peaks in

146 porosity of $66 \%$ as well as opal content of $54 \%$ reveal another diatom-rich layer. Clay

147 content is almost $80 \%$ (Fig. 3). The occurrence of a $10 \mathrm{~m}$ thick package of low density

148 diatom ooze also explains the reversed polarity reflector overlying the inferred glide

149 plane in the unfailed part of the slope (Fig. 2).

150 In summary, both glide planes appear very close to the interface of layers of

151 diatom oozes with increased biogenic opal content and clay-rich sediment on top. Other

152 diatom-rich layers away from glide planes (H01-H04, H06, H07, H09) are covered by

153 coarser sediment (Fig. 3). However, owing to the limited vertical seismic resolution of

$1547.5 \mathrm{~m}$ and uncertainties in the core-seismic correlation we cannot exactly determine

155 whether the sediment failed below, inside or above the thin opal rich layers. The weak

156 layer could therefore be the diatom ooze, the overlying clay-rich sediment, or the

157 interface between both layers.

158 DISCUSSION 


\section{Publisher: GSA \\ Journal: GEOL: Geology \\ DOI:10.1130/G39892.1}

Core-seismic integration shows that the glide planes for the Cap Blanc Slide

160 coincide with diatom oozes topped by clay. Diatoms are siliceous microfossils and their

161 presence is known to significantly influence the geotechnical properties of sediments,

162 even in minor amounts. Water content, permeability, compressibility, and angle of

163 friction all increase with the amount of diatoms (Bryant et al. 1981, Tanaka and Locat,

164 1999; Wiemer et al., 2017). High friction angles suggest that diatom ooze would rather

165 act as a barrier to failure rather than a weak layer. However, the diatoms' high

166 compressibility may lead to compaction disequilibrium during burial. Urlaub et al. (2015)

167 numerically modeled the burial of a layer with compressibility similar to that measured

168 for diatom oozes (i.e., $\mathrm{C}_{\mathrm{c}}>1.04$ ) and showed that deposition of sedimentation with rates

169 similar to those encountered off Cap Blanc $(>0.15 \mathrm{~m} / \mathrm{ky})$ could cause sufficient excess

170 pore pressure to destabilize a $2^{\circ}$ slope. In addition to the accumulation of excess pore

171 pressure due to rapid decrease in pore space during compaction, diatoms contain large

172 amounts of intraparticle water stored in their hollow shells and skeletal pores, which is

173 released once the confining stress exceeds a critical threshold and particles crush. Given

174 that intraparticle water in diatom oozes may be as high as $15 \%$ of its dry weight this

175 process could release significant amounts of excess fluid (Tanaka and Locat, 1999).

176 Kokusho and Kojima (2012) showed that the presence of a liquefiable silty layer, such as

177 diatom ooze, at a lower permeability boundary can generate accumulation of water,

178 which could generate a failure surface. Based on these considerations and our results

179 from core-seismic integration we suggest that for the Cap Blanc Slide a bedding sequence

180 of diatom oozes capped by clay may form an induced weak layer (Locat, 2014). We

181 propose the following conceptual model to explain landslides in diatom-rich sediment: 


\section{Publisher: GSA \\ Journal: GEOL: Geology \\ DOI:10.1130/G39892.1}

182 1. Widespread deposition of large amounts of diatoms in hemipelagic sediment is

183 followed by deposition of clay. As a consequence of continuously increasing

184 overburden, the diatom ooze consolidates by vertical drainage of excess pore fluid

185 and subsequent volume loss. Hydrostatic conditions are maintained until the drainage

186 path becomes too long or the permeability of the overlying sediment becomes too low

187 for the excess pore fluid to drain.

188 2. Excess pore fluid is trapped at the interface between the ooze and the overlying clay.

189 As burial and the release of intraparticle water continue, excess pore pressure

190 constantly increases causing the shearing resistance and the shear stress to increase at

191 different rates with increasing depth.

192 3. When the shear stress exceeds the shear strength of the ooze or the clay slope failure

193 occurs. Recalling the high frictional resistance of diatom ooze, failure is more likely

194 to take place in the clay than in the ooze. However, the presence of diatom ooze is

195 crucial as it provides an effective source of pore fluid.

196 The proposed failure mechanism differs to what has been suggested in previous

197 studies that reported on a link between opal and submarine landslide occurrence. Volpi et

198 al. (2003) and Davies and Clark (2006) suggested that water released by the transition of

199 opal-A to opal-CT caused submarine landslides. However, this diagenetic alteration acts

200 at $300-800 \mathrm{~m}$ below seafloor, which is much deeper than the glide planes of mega-slides

201 off NW Africa (50-150 m, Krastel et al. 2012) and most submarine landslides on

202 continental slopes in general (10-100 m, Masson et al., 2010).

203 Potential of Diatom Ooze as a Global and Widespread Weak Layer 


\section{Publisher: GSA \\ Journal: GEOL: Geology \\ DOI:10.1130/G39892.1}

Diatom oozes typically occur in the southern and tropical oceans, as the burial of

205 biogenic opal relies on sufficient supply of silicate and thus high diatom productivity in

206 surface waters. Diatom blooms are also common in upwelling areas along continental

207 margins, where deep, nutrient-rich cold water rises toward the surface. In particular,

208 during glacial times, strong winds and intensified upwelling favors productivity. In the

209 subtropical North Atlantic, a reduction in the formation of silicate poor glacial North

210 Atlantic Intermediate Waters during deglaciations allowed underlying silicate rich deeper

211 water to increase the silicate supply to the surface ocean, which led to the formation of

212 diatom oozes at ODP Site 658 and other places along the entire Western African

213 continental margin (Meckler et al., 2013). It therefore seems plausible that shallow $(<100$

$214 \mathrm{~m}$ ) high amplitude seismic reflectors observed in high resolution seismic data along this

215 margin represent diatom ooze layers in contact with hemipelagic sediment. The potential

216 critical role of diatom oozes not only for the Cap Blanc but also for the generation of the

217 Sahara, Mauritania, and Dakar slides is evident as the glide planes coincide with such

218 reflectors (Antobreh and Krastel, 2007, and the Data Repository).

219 In the Arctic Ocean, Kristoffersen et al. (2007) combine seismic data with IODP

220 Site M0004 to identify the interface between diatom ooze and overlying silty clay as the

221 glide planes for seven landslides on the Lomonosov Ridge. Pittenger et al. (1989) and

222 Busch and Keller (1982) have considered diatom oozes as potentially unstable at the

223 Vøring Plateau, Norway, and in one of the largest upwelling areas worldwide, the

224 Peruvian continental margin. The lowermost headwall in the Storegga Slide complex

225 formed in siliceous biogenic oozes, potentially leading to the initiation of the entire

226 Storegga Slide (Riis et al. 2005). Our study provides direct evidence for diatom ooze as 


\section{Publisher: GSA \\ Journal: GEOL: Geology \\ DOI:10.1130/G39892.1}

227 weak layer for the Cap Blanc Slide. Combined with the above considerations from other

228 continental slopes, this suggests that burial and loading of diatom oozes covered by clay

229 could be an important preconditioning factor for many submarine landslides globally. To

230 improve understanding of this process and due to the large variety of diatom species,

231 which may have fundamentally different mechanical behaviors, future work should focus

232 on analyzing the nature and evolution of the microfossil skeletons in the oozes that are

233 suspected to act as weak layers.

\section{ACKNOWLEDGMENTS}

We thank the captain and crew of RV Maria S. Merian cruise 11/2, as well as the

236 watchkeepers for seismic and hydroacoustic systems. Sascha Fricke is acknowledged for

237 seismic data processing. We thank A. Georgiopoulou, Tanaka, J. Locat, A. Camerlenghi,

238 and three anonymous reviewers for their detailed comments, which substantially

239 improved the paper.

\section{REFERENCES CITED}

241 Antobreh, A.A., and Krastel, S., 2007, Mauritania Slide Complex: morphology, seismic

242 characterisation and processes of formation: International Journal of Earth Sciences, v. 96, p. 451-472, https://doi.org/10.1007/s00531-006-0112-8.

244 Bondevik, S., Lovholt, F., Harbitz, C., Mangerud, J., Dawson, A., and Svendsen, J.I.,

2452005 , The Storegga Slide tsunami-comparing field observations with numerical

246 simulations: Marine and Petroleum Geology, v. 22, p. 195-208,

$247 \quad$ https://doi.org/10.1016/j.marpetgeo.2004.10.003. 
Publisher: GSA

Journal: GEOL: Geology

DOI:10.1130/G39892.1

248 Bryant,W.R., Bennett, R.H., and Katerman, C.E., 1981, Shear strength, consolidation,

249 porosity, and permeability of oceanic sediments, in: Emiliani, C., ed., The Sea,

250 J.Wiley \& Sons, NewYork, , v. 7, p. 1555-1616.

251 Busch, W.H., and Keller, G.H., 1982, Consolidation characteristics of sediments from the

252 Peru-Chile continental margin and implications for past sediment instability: Marine

253 Geology, v. 45, p. 17-39, https://doi.org/10.1016/0025-3227(82)90178-5.

254 Dan, G., Sultan, N., and Savoye, B., 2007, The 1979 Nice harbour catastrophe revisited:

255 Trigger mechanism inferred from geotechnical measurements and numerical

256 modelling: Marine Geology, v. 245, p. 40-64,

257 https://doi.org/10.1016/j.margeo.2007.06.011.

258 Davies, R.J., and Clark, I.R., 2006, Submarine slope failure primed and triggered by

259 silica and its diagenesis: Basin Research, v. 18, p. 339-350,

$260 \quad$ https://doi.org/10.1111/j.1365-2117.2006.00297.x.

261 Kokusho, T., and Kojima, T., 2002, Mechanism for postliquefaction water film

262 generation in layered sand. J Geotech Geoenviron Eng, v. 128, p.129-137..

263 Krastel, S., Wynn, R.B., Georgiopoulou, A., Geersen, J., Henrich, R., Meyer, M., and

264 Schwenk, T., 2012, Large-scale mass wasting on the Northwest African Continental

265 Margin: Some general Implications for mass wasting on passive continental margins,

266 in Yamada, Y., et al., eds., Submarine Mass Movements and Their Consequences:

267 Dordrecht, Netherlands, Springer, Advances in Natural and Technological Hazards

268 Research, v. 31, p. 189-199, doi:10.1007/978-94-007-2162-3_17. 
Publisher: GSA

Journal: GEOL: Geology

DOI:10.1130/G39892.1

269 Kristoffersen, Y., Coakley, B.J., Hall, J.K., and Edwards, M., 2007, Mass wasting on the

270 submarine Lomonosov Ridge, central Arctic Ocean: Marine Geology, v. 243,

271 p. 132-142, https://doi.org/10.1016/j.margeo.2007.04.012.

272 Kvalstad, T.J., Andresen, L., Forsberg, C.F., Berg, K., Bryn, P., and Wangen, M., 2005,

273 The Storegga Slide: Evaluation of triggering sources and slide mechanics: Marine

274 and Petroleum Geology, v. 22, p. 245-256,

$275 \quad$ https://doi.org/10.1016/j.marpetgeo.2004.10.019.

276 L'Heureux, J.-S., et al., 2012, Identification of Weak Layers and Their Role for the

277 Stability of Slopes at Finneidfjord, Northern Norway, in Yamada, Y., et al., eds.,

278 Submarine Mass Movements and Their Consequences: Dordrecht, Netherlands,

279 Springer, Advances in Natural and Technological Hazards Research, v. 31, p. 321-

$280 \quad 330$, doi:10.1007/978-94-007-2162-3_29.

281 Locat, J., 2014, Weak Layers: Their Definition and Classification from a Geotechnical

282 Perspective, in Krastel, S., et al., eds., Submarine Mass Movements and Their

283 Consequences: Dordrecht, Netherlands, Springer, Advances in Natural and

284 Technological Hazards Research, v. 37, p. 3-12, https://doi.org/10.1007/978-3-319-

$285 \quad 00972-8$.

286 Masson, D.G., Harbitz, C.B., Wynn, R.B., Pedersen, G., and Løvholt, F., 2006,

287 Submarine landslides: Processes, triggers and hazard prediction: Philosophical

288 Transactions of the Royal Society A, v. 364, p. 2009-2039,

289 https://doi.org/10.1098/rsta.2006.1810.

290 Masson, D.G., Wynn, R.B., and Talling, P.J., 2010, Large Landslides on Passive

291 Continental Margins: Processes, Hypotheses and Outstanding Questions, in Mosher, 
Publisher: GSA

Journal: GEOL: Geology

DOI: $10.1130 / \mathrm{G} 39892.1$

D.C., et al., eds., Submarine Mass Movements and Their Consequences: Dordrecht,

293 Netherlands, Springer, Advances in Natural and Technological Hazards Research, v. 28, p. 153-165, doi:10.1007/978-90-481-3071-9_13.

Meckler, A., Sigman, D., Gibson, K., François, R., Martinez-Garcia, A., Jaccard, S.,

296 Röhl, U., Peterson, L.C., Tiedemann, R., and Haug, G., 2013, Deglacial pulses of

297 deep-ocean silicate into the subtropical North Atlantic Ocean: Nature, v. 495,

298 p. $495-498$, https://doi.org/10.1038/nature12006.

299 Milliman, J.D., and Syvitski, J.P.M., 1992, Geomorphic/tectonic control of sediment

300 discharge to the ocean: The importance of small mountaineous rivers: The Journal of

301 Geology, v. 100, p. 525-544, https://doi.org/10.1086/629606.

302 Pittenger, A., Taylor, E., and Bryant, W.R., 1989, The influence of biogenic silica on the

303 geotechnical stratigraphy of the Voring Plateau, Norwegian Sea, in Eldholm, O., et

304 al., eds., Proceedings of the Ocean Drilling Program, Scientific Results: College

305 Station, Texas, Ocean Drilling Program, v. 104, p. 923-940,

306 doi:10.2973/odp.proc.sr.104.145.1989.

307 Press, F., 1966, Section 9: Seismic velocities: Geological Society of America Memoir 97, $308 \quad$ p. $195-218$.

309 Riis, F., Berg, K., Cartwright, J.A., Eidvin, T., and Hansch, K., 2005, Formation of huge

310 crater structures in ooze sediments in the Norwegian Sea. Possible implications for

311 the triggering of the Storegga Slide: Marine and Petroleum Geology, v. 22, p. $257-$

$312 \quad$ 273, httpsdoi:10.1016/j.marpetgeo.2004.10.023. 


\section{Publisher: GSA \\ Journal: GEOL: Geology \\ DOI: $10.1130 / \mathrm{G} 39892.1$}

313 Tanaka, H., and Locat, J., 1999, A microstructural investigation of Osaka Bay clay: The

314 impact of microfossils on its mechanical behaviour: Canadian Geotechnical Journal,

315 v. 36, p. $493-508$, https://doi.org/10.1139/t99-009.

316 Tiedemann, R., 1991, Acht Millionen Jahre Klimageschichte von Nordwest Afrika und

317 Paläo-Ozeanographie des angrenzenden Atlantik: Hochauflösende Zeitreihen von

318 ODP-Sites 658-661 [Ph.D. Thesis]: Kiel, Germany, University of Kiel, 127 p.

319 Urlaub, M., Talling, P.J., Zervos, A., and Masson, D., 2015, What causes large submarine

$320 \quad$ landslides on low gradient $\left(<2^{\circ}\right)$ continental slopes with slow $(\sim 0.15 \mathrm{~m} / \mathrm{kyr})$

321 sediment accumulation?: Journal of Geophysical Research. Solid Earth, v. 120,

322 p. 6722-6739, https://doi.org/10.1002/2015JB012347.

323 Voight, B., Janda, R.J., and Glicken, H., 1983, Nature and mechanics of the Mount St.

324 Helens rockslide-avalanche of 18 May 1980: Geotechnique, v. 33, p. 243-273,

325 https://doi.org/10.1680/geot.1983.33.3.243.

326 Volpi, V., Camerlenghi, A., Hillenbrand, C.-D., Rebesco, M., and Ivaldi, R., 2003,

327 Effects of biogenic silica on sediment compaction and slope stability on the Pacific

328 margin of the Antarctic Peninsula: Basin Research, v. 15, p. 339-363,

329 https://doi.org/10.1046/j.1365-2117.2003.00210.x.

330 Wiemer, G., Dziadek, R., and Kopf, A., 2017, The enigmatic consolidation of

331 diatomaceous sediment: Marine Geology, v. 385, p. 173-184,

332 https://doi.org/10.1016/j.margeo.2017.01.006.

\section{FIGURE CAPTIONS}




\section{Publisher: GSA \\ Journal: GEOL: Geology \\ DOI:10.1130/G39892.1}

336 Figure 1. Bathymetric map of the Cap Blanc Slide showing the scarps of a larger

337 ('major') and a smaller ('minor') landslide. ODP Site 658 marked by the red dot was

338 drilled inside the failed area of the major slide. The black solid line shows the location of

339 seismic profile GeoB09-040. The inset shows GEBCO bathymetry of the Northwest

340 African continental slope $(\mathrm{WS}=$ Western Sahara, MAU $=$ Mauritania, $\mathrm{SN}=$ Senegal $)$

341 including the location of the main figure (red rectangle).

343 Figure 2. Seismic reflection line GeoB09-040 across the Cap Blanc Slide area and ODP

344 Site 658 (green vertical line). Colored arrows indicate the glide planes corresponding to

345 the minor slide (purple), the major slide (red) and the buried slide (blue). Nine prominent

346 high-amplitude reflectors are termed H01-H09. See Figure 1 for location of the profile

347 and the GSA Data Repository (see footnote 1) for an enlarged and uninterpreted version

348 of the profile.

350 Figure 3. Core data from ODP Site 658 from left to right: bulk density, $\rho_{\text {GRA }}$ (from

351 Gamma Ray Attenuation measurements, filtered for realistic values); porosity (black) and

352 water content (gray) from Moisture And Density measurements; biogenic silica

353 equivalent to opal content of the sediment fraction $>2 \mu \mathrm{m}$ determined by density

354 separation, $\mathrm{bSiO}_{2}$ (black), and element log-ratio of silica to aluminum, $\ln (\mathrm{Si} / \mathrm{Al}$ ) (gray);

355 clay content (i.e. sediment fraction $<2 \mu \mathrm{m}$ ). X-ray fluorescence scanning-derived element

356 log-ratio of silica to aluminum counts $(\ln (\mathrm{Si} / \mathrm{Al})$, Meckler et al. 2013) is a proxy for

357 sediment opal content. Average sample distances are $1.5 \mathrm{~m}(0-100 \mathrm{~m})$ and $2.5 \mathrm{~m}(100-$

$358200 \mathrm{~m}$ ). Seismic reflectors H01-H09 are shaded in gray with an uncertainty of $\pm 2 \mathrm{~m}$ 


\section{Publisher: GSA \\ Journal: GEOL: Geology \\ DOI:10.1130/G39892.1}

359 owing to the vertical resolution of the seismic data, i.e., $1 / 4$ of the wavelength. Dashed

360 lines indicate the inferred glide planes for the minor (purple), the major (red) and the

361 buried (blue) slides.

362

363 1GSA Data Repository item 2018xxx, description of methodology and high-resolution

364 image of the seismic transects without interpretation, is available online at

365 http://www.geosociety.org/datarepository/2018/ or on request from

366 editing@geosociety.org. 


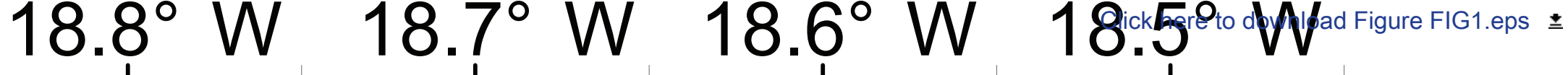

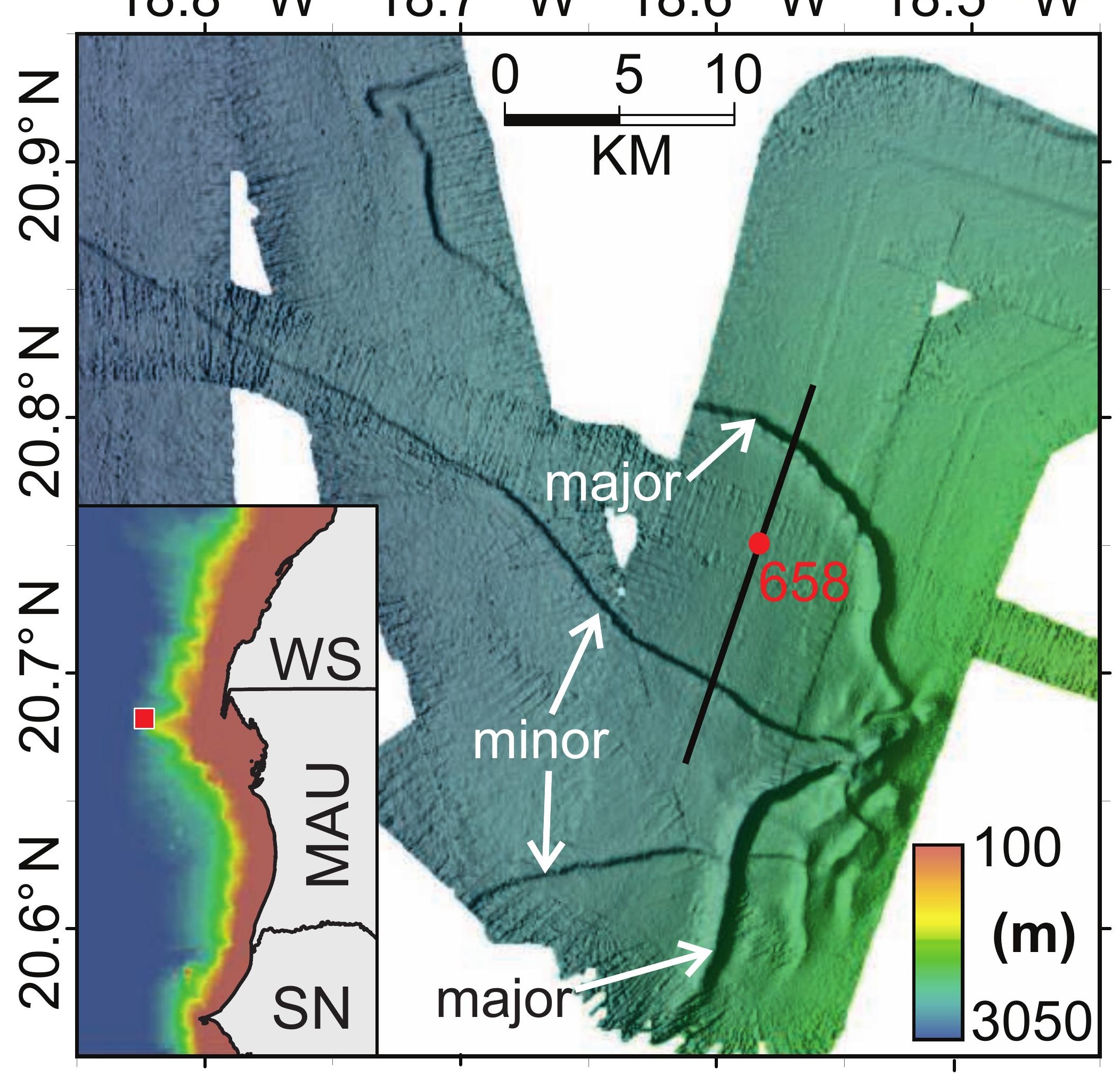




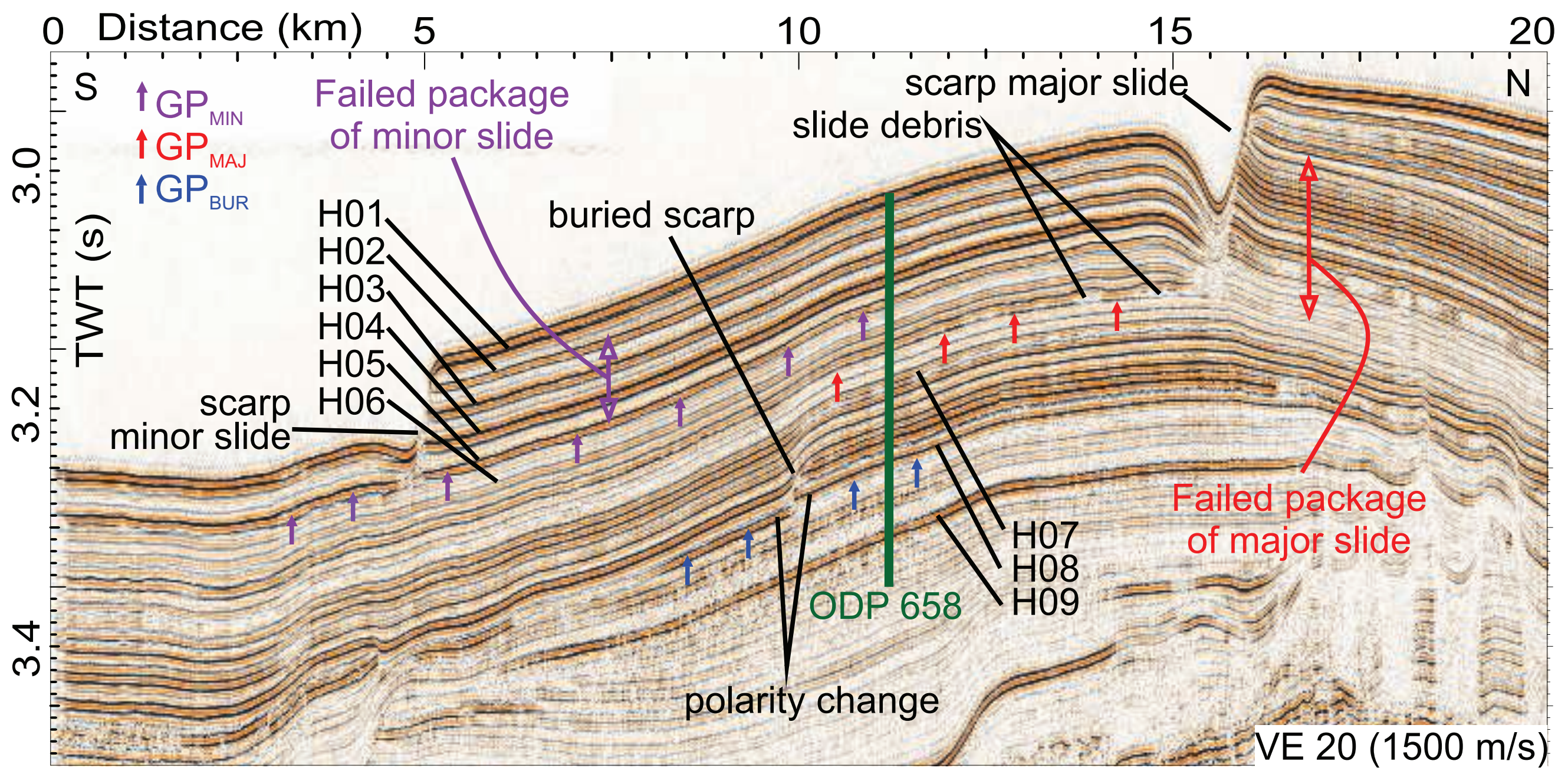



$\begin{array}{lllll}50 & 100 & 2 & 3 & 4\end{array}$

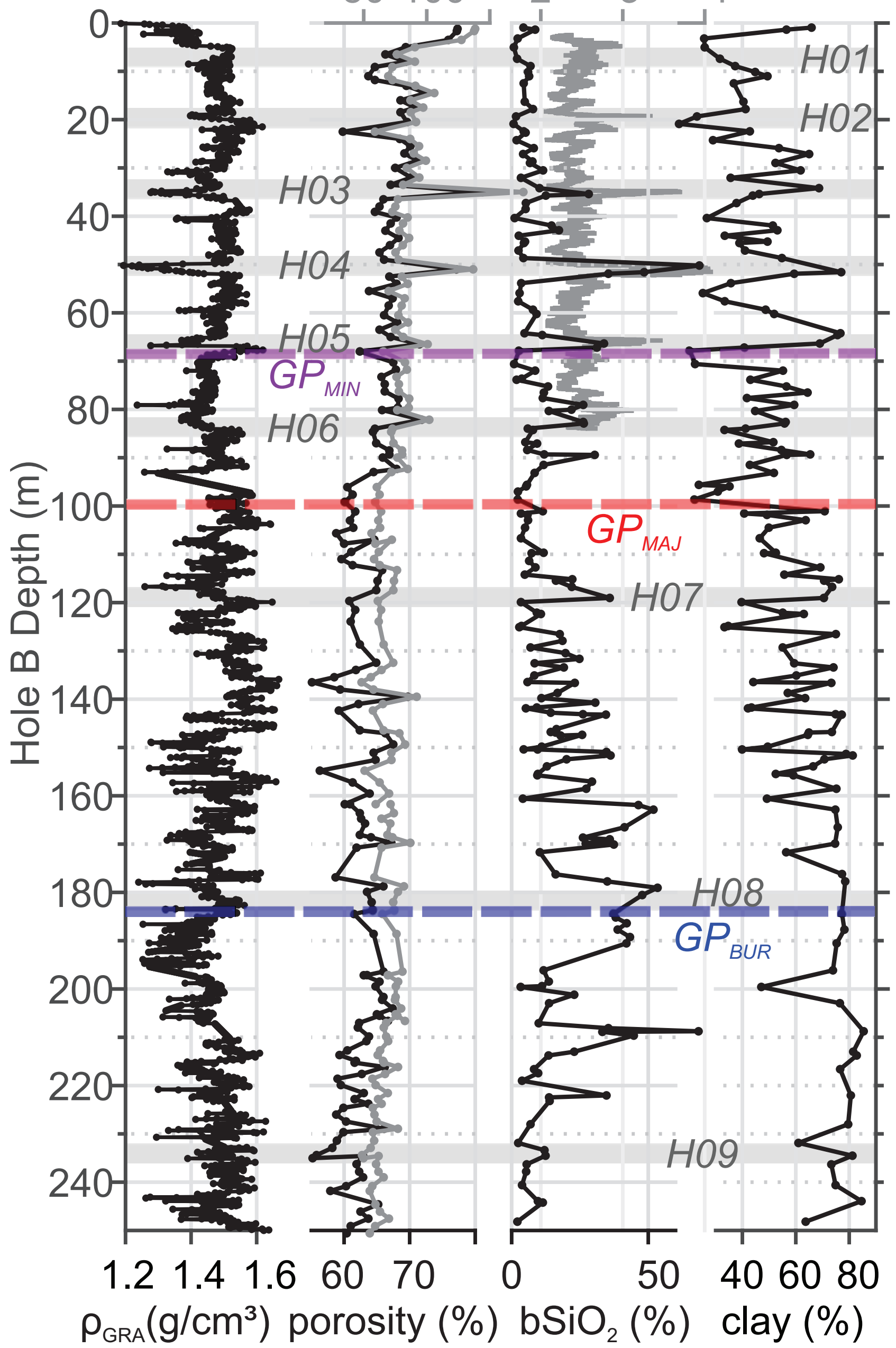




\title{
Text and figures for GSA Data Repository to accompany \\ "Diatom ooze: Crucial for the generation of submarine mega-slides" \\ by Urlaub, M., Geersen, J., Krastel, S., and Schwenk, T.
}

\begin{abstract}
Methodology
Acoustic data

Multibeam bathymetric data was collected during cruise MSM11/2 in 2009 with the hull-mounted Kongsberg Simrad symstem EM120. Processing was carried out with open source software MBSystem and Fledermaus Pro (QPS) to create a grid with $50 \mathrm{~m}$ resolution. During the same leg 2D highresolution multichannel seismic data were acquired using a GI Gun with 2x 1.71 chamber volume (main frequencies between 100 and $200 \mathrm{~Hz}$ ) and a $500 \mathrm{~m}$ long analogue streamer hosting 80 channels. Seismic data processing was carried out with VISTA (Schlumberger) and included binning with $5 \mathrm{~m}$ size, trace editing, NMO correction and stacking as well as migration. The data is capable of resolving layers with thickness as low as $7 \mathrm{~m}$.
\end{abstract}

\section{Core-seismic integration}

We calculate the synthetic seismogram for ODP site 658 based on densities determined from GammaRay-Attenuation (GRA) and a constant p-wave velocity of $1500 \mathrm{~m} / \mathrm{s}$. Due to expansion of free gas in the sediment during core recovery reliable measurements of p-wave velocity are only available for the upper $10 \mathrm{~m}$ of the core (Ruddiman et al., 1988). However, velocity values normally scatter around a mean trend and variations in marine surface sediments do not exceed $5 \%$, whereas density variations are much higher $(>20 \%)$ within these sediments (e.g. Breitzke, 2000). Velocity data are thus less important for the calculation of reflection coefficients in this specific environment. Therefore, an initial constant $\mathrm{p}$-wave velocity of $1500 \mathrm{~m} / \mathrm{s}$ was used for the whole length of the core.

GRA density values are available for ODP cores 658A, B and $\mathrm{C}$ at an interval of about $0.6 \mathrm{~cm}$ including several gaps of up to a few meters. Although core A represents the longest record, values for the upper $165 \mathrm{~m}$ were taken from core B as it contains less and smaller gaps. Problems with GRA density measurements occur where the core liner is not entirely filled with sediment or where there is gas expanding in the sediment. In situ this gas was most likely dissolved in the pore water as the high resolution seismic data does not show any evidence for free gas. Already 1-3\% of free gas would reduce the P-wave velocity significantly enough to create a bright spot or blanking in the seismic data (considering the high frequencies of our data around $100 \mathrm{~Hz}$ ) (e.g. Singh et al., 19930 or Minshull et al., 1994). Hence to avoid density values affected by free gas (and thus conditions that are not representative to those in the seafloor) the density data is filtered to eliminate values lower than 1.025 $\mathrm{g} / \mathrm{cm}^{3}$, equal to the density of seawater (a lower value may only occur if gas is present in the pore space). We also apply a high-cut filter for values larger than $2.7 \mathrm{~g} / \mathrm{cm}^{3}$ (representing the density of clay 
or silt particles). Furthermore, the central value of a running average of 300 data points is compared to the mean of the data window. For differences greater than $0.25 \mathrm{~g} / \mathrm{cm}^{3}$ the value is deleted. We then calculate standard deviations for a moving 50 points window. Each value is compared to the mean of the 50 neighboring points and if the difference is larger than twice the standard deviation for the window it is eliminated. The filtering of GRA - density lead to a reduction of data points from 38516 to 33165 values. Filtering also caused gaps in the density data in some locations (e.g. between 97 and $100 \mathrm{mbsf}$ and 209 and $212 \mathrm{mbsf}$ ). In order to avoid artificial reflectors produced by these data gaps we linearly interpolated to the next density value. The filtered and interpolated data was finally used for the calculation of a synthetic seismogram. As the part below $275 \mathrm{~m}$ is mainly represented by two large gaps, density data was only used above this depth. Finally, a smoothing of the density record was achieved by the use of a $10 \mathrm{~cm}$ running average. To avoid unrealistic reflection coefficients the data was linearly interpolated at places where gaps in the final density record occurred.

Reflection coefficients are calculated from the density values and constant velocity and convolved with a wavelet, which approximates the seismic signal observed in the field. As a source wavelet a standard Ricker wavelet (Ricker, 1953) was preferred over a wavelet extracted from seismic traces near the borehole. The synthetic wavelet appears smoother than the recorded one and has proven to be more useful for a visual correlation of measured and synthetic data. The wavelet contains a frequency of $100 \mathrm{~Hz}$ corresponding to the dominant frequency of the GI-gun. The sampling rate is $250 \mu$ s which is equivalent to the seismic profile. For the core-seismic integration we use the SynPAK module in the IHS Kingdom ${ }^{\circledR}$ software. The synthetic seismogram is shifted, stretched or squeezed to match the nearby seismic survey traces and the interval velocities are adapted correspondingly. The software recalculates the synthetic using the updated velocity profile. During stretching and squeezing great care was taken that the updated velocities are in a reasonable range for marine sediments $(1.2-4 \mathrm{~m} / \mathrm{s}$, Press 1966).

TABLE S1 High amplitude reflectors, glide planes, and post-failure reflectors providing minimum slide ages identified in the seismic line and tied in to ODP core 658 as a result of core-seismic integration. TWT is two-way-traveltime of individual reflectors at the borehole. We use the age model by Tiedemann (1991).

\begin{tabular}{lccc}
$\begin{array}{c}\text { Seismic } \\
\text { horizon }\end{array}$ & $\begin{array}{c}\text { TWT } \\
(\mathrm{s})\end{array}$ & $\begin{array}{c}\text { Core depth } \\
(\mathrm{m})\end{array}$ & $\begin{array}{c}\text { Age } \\
(\mathrm{ka})\end{array}$ \\
\hline \hline H01 & 3.029 & 7 & 50 \\
H02 & 3.046 & 20 & 149 \\
H03 & 3.065 & 35 & 247 \\
H04 & 3.088 & 51 & 342 \\
H05 & 3.107 & 66 & 434 \\
H06 & 3.128 & 83 & 563 \\
H07 & 3.174 & 119 & 1800 \\
H08 & 3.244 & 182 & 2500 \\
H09 & 3.308 & 234 & 2960 \\
\hline
\end{tabular}




\begin{tabular}{lccc} 
GP $_{\text {MIN }}$ & 3.112 & 69 & 434 \\
GP $_{\text {MAJ }}$ & 3.151 & 100 & 1573 \\
GP $_{\text {BUR }}$ & 3.248 & 183 & 2500 \\
\hline Post $_{\text {MIN }}$ & 3.046 & 20 & 149 \\
Post $_{\text {MAJ }}$ & 3.151 & 100 & 731 \\
Post $_{\text {BUR }}$ & 3.215 & 154 & 2300 \\
\hline
\end{tabular}




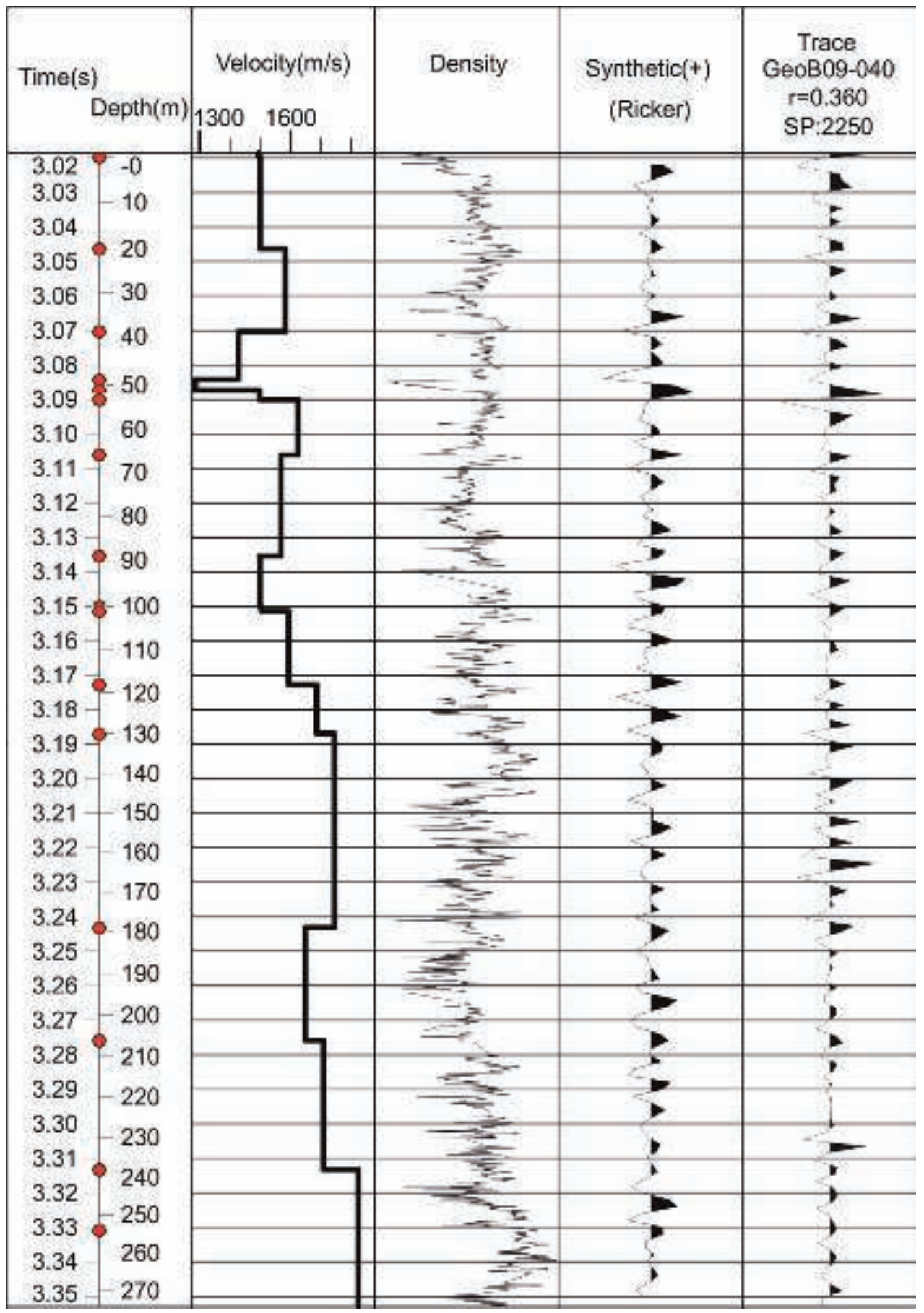

Figure S1: Core seismic integration correlation panel. The synthetic seismogram was shifted, stretched or squeezed to match the nearby seismic survey traces and the interval velocities are adapted correspondingly.The synthetic seismogram is recalculated using the new velocity profile after each adjustment. 


\section{References}

Breitzke, M. (2000). Acoustic and elastic characterization of marine sediments by analysis, modeling, and inversion of ultrasonic P wave transmission seismograms. Journal of Geophysical Research: Solid Earth, 105(B9), 21411-21430.

Minshull, T.A., Singh, S., Westbrook, G.K. (1994). Seismic velocity structure at a gas hydrate reflector, offshore western Colombia, from full waveform inversion. Journal of Geophysical Research: Solide Earth, 99(B3), 4715-4743.

Press, F. (1966). Section 9: Seismic velocities. Geological Society of America Memoirs, 97, 195-218. Ricker, N. (1953). Wavelet contraction, wavelet expansion, and the control of seismic resolution. Geophysics, 18(4), 769-792.

Ruddiman, W., Sarnthein, M., Baldauf, J., et al., 1988. Proc. ODP, Init. Repts., 108: College Station, TX (Ocean Drilling Program).

Singh, S., Minshull, T.A., Spence, G.D. (1993). Velocity Structure of a Gas Hydrate Reflector. Science, 260, 5105, 204-207.

Tiedemann, R., 1991. Acht Millionene Jahre Klimageschichte von Nordwest Afrika und PaläoOzeanographie des angrenzenden Atlantik: Hochauflösende Zeitreihen von ODP-Sites 658-661. [Ph.D. thesis]: University of Kiel, Germany, 127 p.

\section{Additional figures}

Figure S2: Seismic line GeoB09-040 uninterpreted and at high resolution.

Figure S3: Seismic line GeoB03-017 downslope that crosses line GeoB09-040 at a right angle at ODP Site 658 .

Figure S4: High resolution seismic lines showing high amplitude reflectors that are typical for the shallow sediments on the continental slope of Northwest Africa and that coincide with landslide scars for A) Sahara Slide, B) Mauritania Slide, and C) Dakar Slide. 


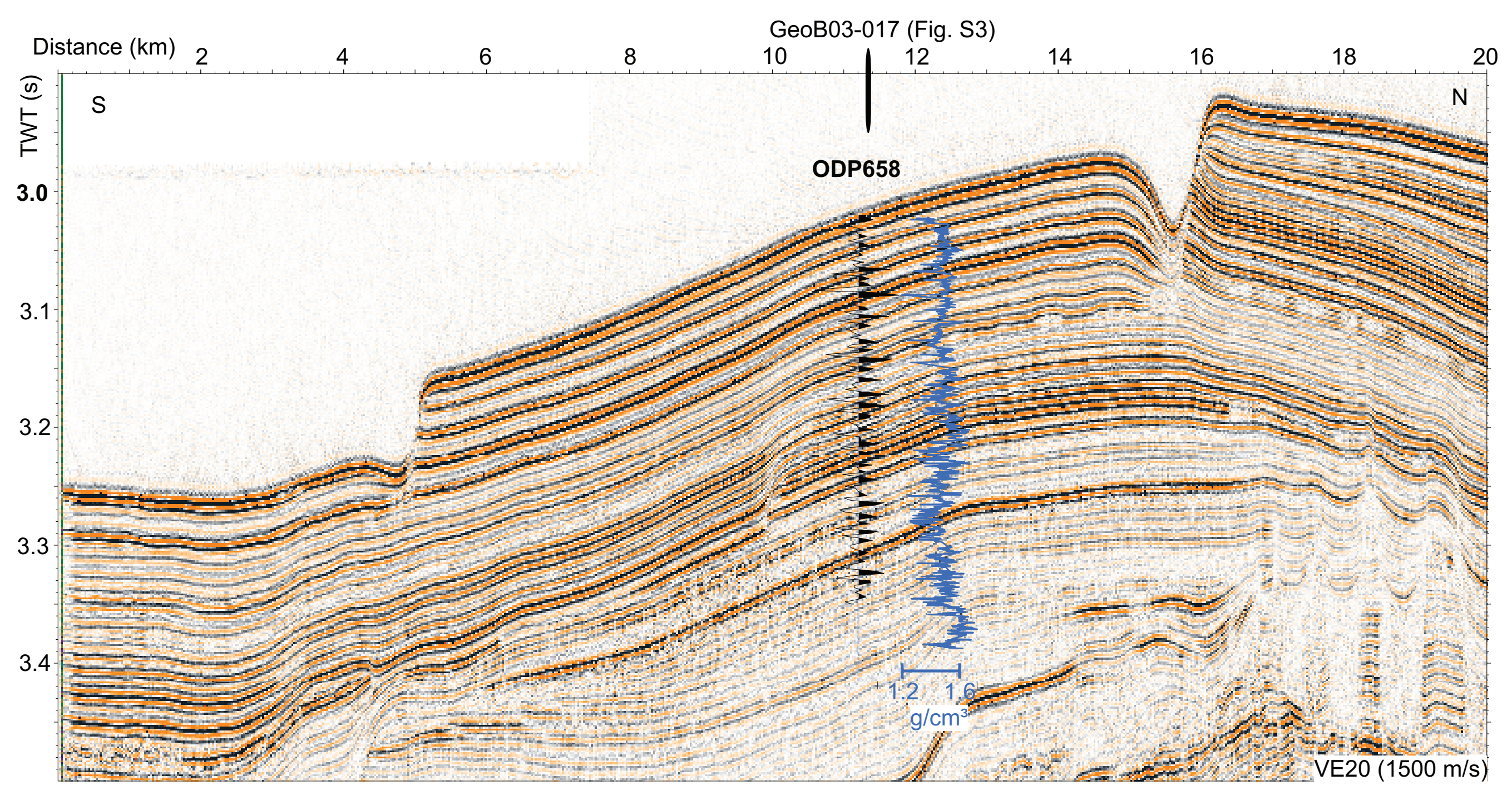

GeoB03-017 (Fig. S3) 


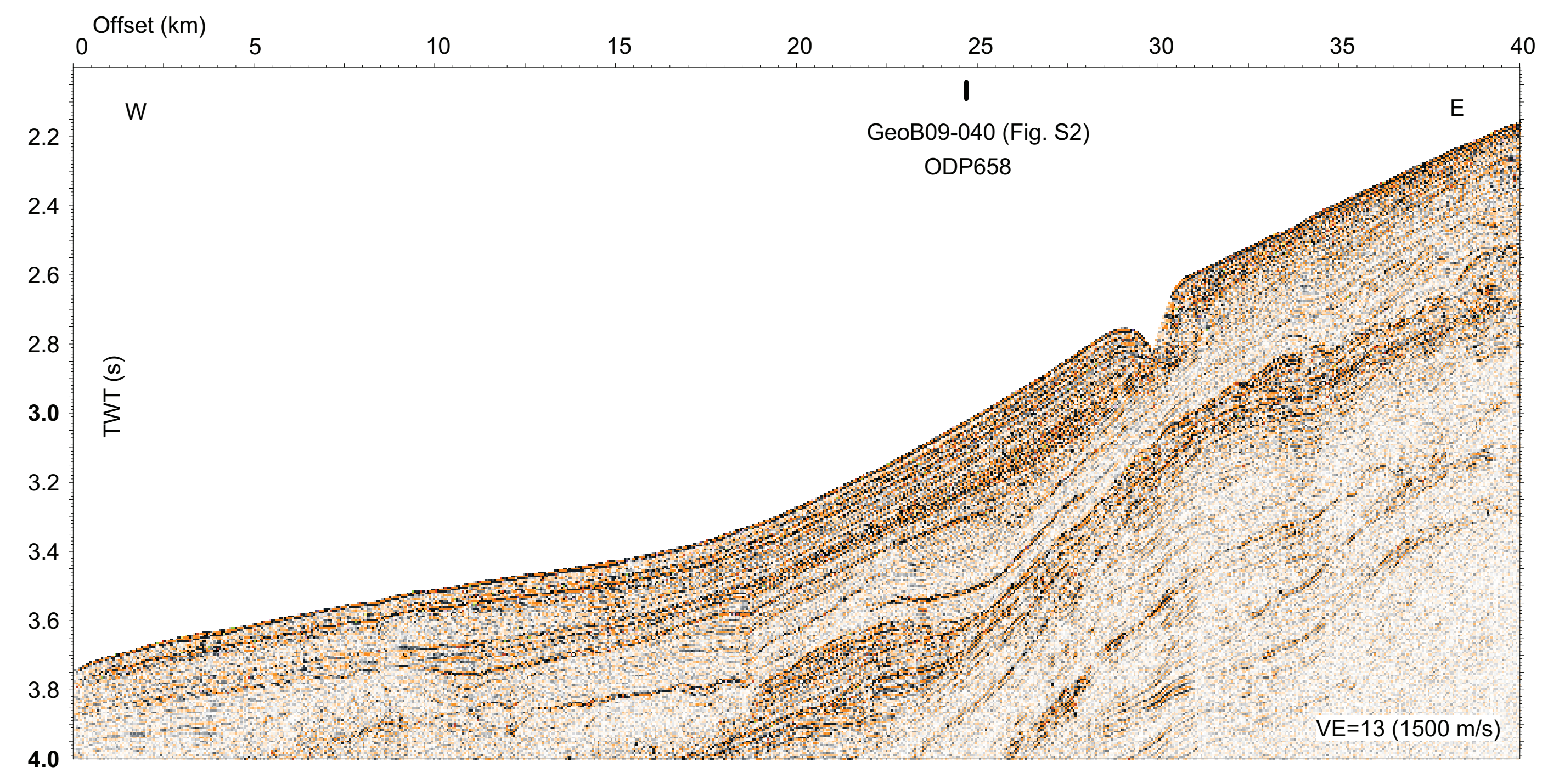



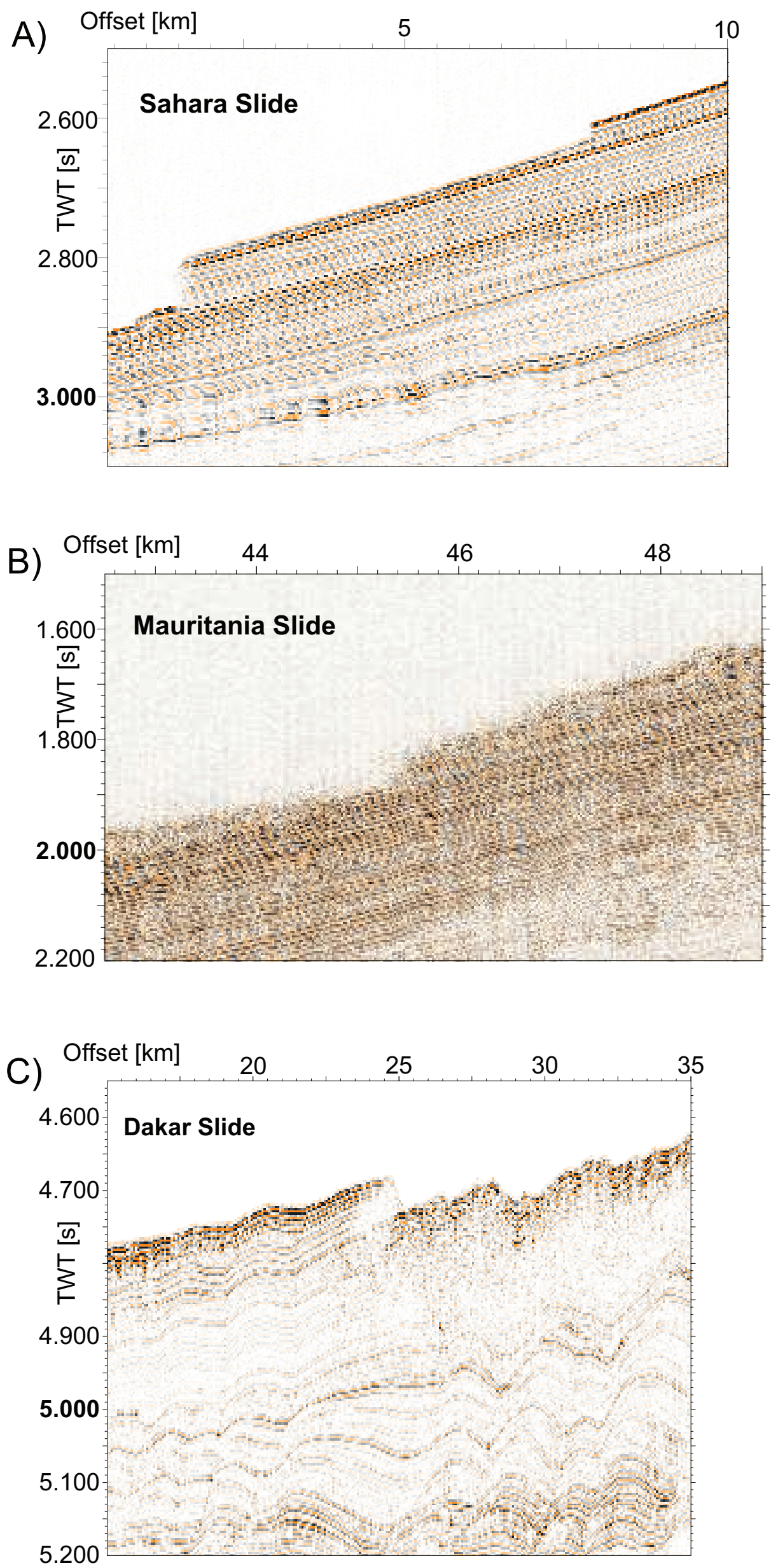